\title{
WĘDRUJĄC ŚLADAMI UMARŁYCH. FOTO-TEKSTY DAŠY DRNDIĆ
}

\author{
SABINA GIERGIEL
}

\begin{abstract}
Following the Footsteps of the Dead. Daša Drndićs Photo-texts.
The starting point for the article is the conviction that in her books, the Croatian author Daša Drndić consistently explores the themes of memory and oblivion about Holocaust and the World War II victims. The paper juxtaposes the excerpts from her two novels: April in Berlin (2009) and EEG (2016). In both of them, the author inserts peculiar photo-texts in which the visual layer mingles with the linguistic one. In the first one, this relation is obvious (photographs and text are set together here), whereas in the second one it is more ambiguous. However, I endeavor to demonstrate that using language, Drndić manages to create the unusual graphic "pictures in motion" that simultaneously envision the contemporary Zagreb as well as the same city from the 1940s. The interpretation of such fragments is additionally enhanced with the considerations on the Croatian capital city's space which is filled with multiple signs of "difficult heritage" (Sharon Macdonald's term).
\end{abstract}

STRESZCZENIE. Punktem wyjścia niniejszego tekstu jest przekonanie, że chorwacka autorka Daša Drndić w kolejnych swoich książkach konsekwentnie eksploatuje tematykę pamięci i zapomnienia o Holokauście oraz o ofiarach z czasów drugiej wojny światowej. W artykule zestawione zostają fragmenty z dwóch książek April u Berlinu z 2009 r. i EEG z 2016 r. W obu autorka umieszcza rodzaj foto-tekstów, w których dochodzi do połączenia warstwy wizualnej z językową. W pierwszej z nich ten związek jest oczywisty (mamy tam bowiem zestawienie fotografii i tekstu), w drugiej zaś nie jest jednoznaczny, choć staram się wykazać, że Drndić udało się przy pomocą języka stworzyć niezwykle plastyczne „obrazy w ruchu”, w których nałożone zostają na siebie sceny z dzisiejszego Zagrzebia i z lat $40 \mathrm{XX}$ w. Interpretacja tego rodzaju fragmentów zostaje ponadto uzupełniona o rozważania na temat przestrzeni chorwackiej stolicy, w której brakuje znaków świadczących o ,,trudnym dziedzictwie" (termin Sharon Macdonald).

Author: Sabina Giergiel, Uniwersytet Opolski, Wydział Filologiczny, Pl. Kopernika 11, 45-040 Opole, Polska, sgiergiel@uni.opole.pl, ORCID iD: https://orcid.org/0000-0002-5706-5679

Keywords: Daša Drndić, literature, memory, photography, Zagreb, space, archive

Słowa kluczowe: Daša Drndić, literature, fotografia, Zagrzeb, przestrzeń, archiwum

Balcanica Posnaniensia. Acta et studia, XXV, Poznań 2018, Wydawnictwo Instytutu Historii UAM, pp. 181196, ISBN 978-83-65663-94-8, ISSN 0239-4278. Polish text with summaries in English and Polish.

doi.org/10.14746/bp.2018.25.11

Chorwacka pisarka - Daša Drndić - to autorka, której wyobraźnia twórcza koncentruje się wokół problematyki Zagłady oraz semantyki (nie)pamięci. W swoich kolejnych utworach konsekwentnie powraca do kwestii wytrawienia pamięci europejskiej i do 
aksjologicznie dwuznacznych epizodów z przeszłości Chorwacji. Jej twórczość jest mocno osadzona w kontekście etycznym, można ją odczytywać jako rodzaj apelu do czytelnika, aby nie pozostawał biernym i reagował. Literatura ta nie pozostawia obojętnym, niepokoi. może wręcz szokować nieprzejednanie, z jakim Drndić tropi zło (zarówno we współczesnym świecie, jak i przeszłości), opisuje je i nazywa. Przechodząc od tych ogólnych stwierdzeń na poziom osobisty (nie zawsze mile widziany w tekstach naukowych) przyznać należy, że jest to autorka, od której niezwykle trudno się uwolnić, jej teksty stawiają bowiem przed odbiorcą szereg pytań, są niezwykle gęste znaczeniowo, skomplikowane pod względem formalnym i erudycyjne.

Niniejszy tekst został skonstruowany wokół kilku kluczowych pojęć, a mianowicie: archiwum, fotografii, przedmiotu i przestrzeni. Wszystkie one istnieją w ścisłym powiązaniu z pamięcią i powracać będą $\mathrm{w}$ wielorakich, niejednokrotnie nakładających się na siebie kontekstach.

\section{ARCHIWUM}

Na użytek zaprezentowanych tutaj rozważań fragmenty zakłócające linearny tok narracji, a mianowicie różnego rodzaju spisy, listy, kolekcje (m. in. fotograficzne), dopełniające w książkach Drndić tekst właściwy, nazwane zostają archiwami w mikroskali. Wychodząc od słownikowej definicji pojęcia archiwum, która określa je jako: zbiór dokumentów, pism, akt nieaktualnych już, ale wartych zachowania ${ }^{1}$, materialny zeksterioryzowany korpus pamięci instytucji [...], społeczności lub jednostki, a szerzej zewnętrzne repozytorium pamięci indywidualnej i/lub zbiorowej ${ }^{2}$ uznać należy, że pewnym strategiom chorwackiej prozaiczki przyświeca podobny cel, jaki stawiają przed sobą instytucje archiwizujące. Najogólniej rzecz ujmując, można powiedzieć, że na szczególny projekt pisarki składają się działania, które mają na celu wydobycie z zapomnienia anonimowych ofiar Holokaustu i przywrócenie o nich pamięci. Tego rodzaju próby można połączyć z wielokrotnie współcześnie komentowaną nieufnością wobec wielkiej historii i przekonaniem o ważności (autentyczności) doświadczenia jednostkowego. Zabiegi, które autorka stosuje - enumeracja, przywoływanie formalnych spisów z czasów drugiej wojny światowej (np. lista zrabowanego żydowskiego mienia z Zagrzebia i Dubrownika ${ }^{3}$ ), umieszczenie w utworze spisu

${ }^{1}$ Hasło: archiwum, w: W. Kopaliński, Stownik wyrazów obcych i zwrotów obcojęzycznych z almanachem, Warszawa 2000, s. 45.

${ }^{2}$ Hasło: archiwum, w: Modi memorandi. Leksykon kultury pamięci, red. M. Saryusz-Wolska, R. Traba, współpraca J. Kalicka, Warszawa 2014, s. 45.

${ }^{3}$ Kartoteka zdeponowana w Rosyjskim Wojennym Archiwum Państwowym, której kopia znajduje się w Muzeum Pamięci Holokaustu w USA. Dokumentuje ona działalność ERR (Einsatzstab Reichsleiter Rosenberg), a dokładnie jej komórki w Zagrzebiu (Der Deutsche General in Agram). Zawiera ona spis skonfiskowanego mienia żydowskiego z Zagrzebia. Spis ten został umieszczony w książce: D. Drndić, EEG, Zaprešić 2016, s. 302-321. 
Żydów deportowanych z Włoch albo zabitych we Włoszech i krajach przez nie okupowanych ${ }^{4}$, czy zestawienie w jednej z książek przedwojennych portretowych zdjęć Żydów ze zdjęciami współczesnych fasad budynków, w których mieszkali5 ${ }^{5}$ - sprawiają, że fragmenty jej opowieści przyjmują postać elementów ogromnego katalogu, encyklopedii umarłych ${ }^{6}$, bądź Księgi Pamięci ${ }^{7}$.

Szczególnie interesujące wydają się zwłaszcza dwa sposoby przywoływania przeszłości (a zarazem jej swoistego archiwizowania), jakie stosuje chorwacka autorka. W pierwszej kolejności przywołane zostają fotografie, zebrane i umieszczone przez autorkę w książce April u Berlinu, będące wynikiem swoistej obsesji katalogowania, której autorka oddaje się podczas swego stypendium w Wiedniu. Drndić - jak sama mówi - fotografowała tam budynki i badała cudze życia ${ }^{8}$. W drugiej kolejności zostaną przedstawione narracyjne fragmenty opisujące centrum Zagrzebia w latach 40. XX w. Krótka analiza fotografii wraz z umieszczonymi obok podpisami z utworu April u Berlinu (z 2009 r.) prowadzi bezpośrednio do najnowszej książki Chorwatki, a mianowicie do $E E G$ (z 2016 r.). Zabiegi stosowane w obu utworach są bowiem ze sobą zbieżne. Elementem, który je różni jest jedynie medium wykorzystane przez Drndić. Przy próbie określenia ich specyfiki zasadnym wydaje się użycie terminu foto-teksty. Pojęcie to odnosi się do praktyk artystycznych (przede wszystkim fotograficznych), w których ma miejsce wzajemne oddziaływanie obrazu i tekstu. Są to konstrukcje, w których dochodzi do przecięcia się obu technik, języków i metod badawczych ${ }^{9}$. Określenie ,albumu” z książki April u Berlinu mianem fototekstu nie powinno budzić kontrowersji. Nieco inaczej jest w przypadku fragmentów $\mathrm{z}$ utworu $E E G$. Nie mamy tam bowiem do czynienia z bezpośrednio danym obrazem.

${ }^{4}$ Spis obejmuje nazwiska 9000 Żydów i zajmuje w książce blisko 80 stron. D. Drndić, Sonnenschein. Powieść dokumentalna, przeł. D. J. Ćirlić, Wołowiec 2010, s. 173-251. W oryginalnej (tj. chorwackiej) wersji językowej (Sonnenschein. Dokumentarni roman, Zaprešić 2007) lista nazwisk zostaje umieszczona na perforowanych kartkach, co wskazuje na to, że czytelnikowi zostaje dana możliwość ich wyrwania. Zabieg ten pośrednio świadczy o tym, że spis będący elementem utworu, jednocześnie nie jest w nim konieczny. Jasna Lukić twierdzi jednak, że wyrwanie kartek (skutkujące powstaniem luki, pustego miejsca) jest analogiczne do nieobecności, jaką pozostawili po sobie Żydzi. J. Lukić, Bol pamćenia i bol zaborava: (anti)povijesni romani Daše Drndić, „Treća” 2010, nr 2, s. 27.

5 D. Drndić, April u Berlinu, Zaprešić 2009, s. 221-229.

${ }^{6} \mathrm{O}$ encyklopedii umarłych w kontekście twórczości Drndić zob. S. Giergiel, Ocalić pamięcia. Praktyki pamięci i zapominania we wspótczesnej prozie postjugosłowiańskiej, Opole 2012, s. 234. Zob. też. Opowiadanie Danila Kiša Encyklopedia umarlych ze zbioru o tym samym tytule. D. Kiš, Encyklopedia umarlych, przeł., D. Ćirlić-Straszyńska i Ch. Arvanitidis, Warszawa 1991, s. 51-80.

${ }^{7}$ Księgi Pamięci to publikacje poświęcone żydowskiej społeczności zamieszkującej przed wojną miasta Europy. Mają one charakter sentymentalnego powrotu do miejsc, które w wyniku Zagłady zmieniły swój pierwotny charakter. Są kontynuacją tradycyjnych memorbuchów, których początki sięgają XI w. Zob. M. Adamczyk-Garbowska, Uzupetnianie pamięci - izkor bicher jako świadectwo i inspiracja, w: Zagłada Żydów. Pamięć narodowa a pisanie historii w Polsce $i$ we Francji, red. B. Engelking, J. Leociak, D. Libionka, A. Ziębińska-Witek, Lublin 2006, s. 161-170. Zob. też. A. Ubertowska, Świadectwo-traumaglos. Literackie reprezentacje Holokaustu, Kraków 2007, s. 220-221.

${ }^{8}$ Drndić, April u Berlinu, op. cit., s. 219.

${ }^{9}$ M. Michałowska, Foto-teksty. Związi fotografii z narracja, Poznań 2012, s. 12. 
Marianna Michałowska, od której termin zostaje zapożyczony, foto-narracjami określa praktyki, których fundamentem jest zdjęcie (częściej cykl zdjęć), na którego kanwie rodzi się opowieść. Pomimo tego, że w EEG pisarka nie umieszcza fotografii, to przekaz wizualny jest $\mathrm{w}$ tekście intencjonalnie obecny. Narracja jest bowiem tak prowadzona, aby czytelnik odniósł wrażenie, że spogląda na pewien obraz (obraz w ruchu). Zestawienie ze sobą fragmentów z obu książek, połączone ze wskazaniem na wyraźnie istniejące pomiędzy nimi paralele, potwierdza wielokrotnie podkreślaną cechę twórczości Drndić, a mianowicie jej cykliczność, wariacyjność i nieustanne oscylowanie wokół tematu Zagłady ${ }^{10}$.

\section{FOTOGRAFIE}

W książce April u Berlinu obcujemy ze stronami, przypominającymi kartki z albumu, w których dochodzi do zniesienia dystansu czasowego. Poprzedza je informacja: „to jest może jedna setna opowieści i fotografii, które zebrałam"11. Od klasycznego albu$\mathrm{mu}^{12}$ różni je jednak to, że Drndić wyraźnie konfrontuje w nich przeszłość z teraźniejszością, umieszczając obok siebie (najczęściej portretowe) zdjęcia, które przetrwały Zagładę oraz fotografie dzisiejszych fasad kamienic i numerów domów, w których niegdyś portretowani mieszkali. Towarzyszą im w książce krótkie (często niepełne) biografie mieszkańców. Oto przykłady notek umieszczonych przy zdjęciach:

Bertha Herzl (ur. 1 września 1887 r.) i jej mąż Nathan (ur. 6 czerwca 1884 r.). Mieszkali w 2 dzielnicy przy Rembrandtstraße 35. Deportowani do Rygi 3 grudnia 1941 r., a następnie rozstrzelani w pobliskim lesie.

Niecałe dwa miesiące później - 26 stycznia 1942 r. - wraz z kolejnym transportem do Rygi deportowani zostali Elfriede Frischmann (ur. 10 listopada 1933 r.) i jej rodzice: Geza i Ella. Od razu po dotarciu na miejsce cała trójka została zamordowana. Rodzina mieszkała w 1 dzielnicy przy Dorotheergasse 6/13, w samym centrum starego Wiednia. Budynek odrestaurowano, dziś znajduje się w nim słynna kawiarnia Hawelka - miejsce spotkań członków bohemy i malarzy, do której zaglądali miedzy innymi Ludwig Wittgenstein, Zygmunt Freud i Thomas Bernhard

${ }^{10}$ Zob. S. Giergiel, Ocalić pamięcia, w: eadem, Ocalić pamięcia. Praktyki pamięci i zapomnienia we wspótczesnej prozie postjugostowiańskiej, Opole 2012, s. 171-242, A. Zlatar, Tekst, tijelo, trauma, Zagreb 2004, s. 148.

${ }^{11}$ D. Drndić, April u Berlinu, op. cit., s. 220. Wszystkie tłumaczenie, o ile nie zaznaczono inaczej pochodzą od autora tekstu. Podejmowane w Wiedniu działania Drndić zarówno w swej warstwie ideowej, jak i praktycznej nasuwają skojarzenia z zakrojonym na znacznie szerszą skalę projektem Daniela Libeskinda Star Matrix wyczerpująco omówionym przez Ewę Rewers: Ślady i szkice, w: eadem, Postpolis. Wstęp do filozofii ponowoczesnego miasta, Kraków 2005, s. 34-42.

${ }^{12}$ Gdyby nie komponent odnoszący się do współczesności, projekt Drndić przypominałby np. wydany przez Państwowe Muzeum na Majdanku w 2014 r. album fotograficzny zatytułowany Każda ofiara ma imię-Every victim has a name, Lublin 2014. 
Robotnik Leopold Götzel, ur. 18 maja 1898 r. w Wiedniu. Mieszkał w 2 dzielnicy przy Engerthstraße 230/7/5. Ucieka do Francji, tam 4 września 1942 r. zostaje internowany w Drancy. Następnie deportowany do Auschwitz i tam zamordowany ${ }^{13}$.

Chorwatka prowadzi w Wiedniu rodzaj śledztwa (którego konstytutywnym elementem jest poszukiwanie śladów i zapisywanie wyników poszukiwań), a następnie rekonstruuje pewien aspekt przeszłości konkretnych miejsc.

Należy podkreślić, że [w] każdym przedstawieniu fotograficznym tu $i$ teraz widzów - ich zdolność korzystania z różnych kontekstów wyjaśniajacych - jest czytana $w$ relacji do tam $i$ wtedy sfotografowanego momentu ${ }^{14}$. A zatem umieszczone w książce krótkie notki z towarzyszącymi im zdjęciami, stają się, przefiltrowanymi przez wiedzę o końcu ich bohaterów, dowodami istnienia. Te foto-teksty (następujące po sobie zestawienia informacji dotyczących jednej osoby, pary, bądź rodziny) z książki April u Berlinu, stanowią

pojedynczy case (przypadek), reprezentujący ludzkie losy w indywidualnej perspektywie, a także stanowiący odniesienie do losów innych. [...] W foto-tekście zostaje zapisany fragment prywatnej i społecznej pamięci, z kolei narracja wydaje się jednym z najbardziej naturalnych sposobów dotarcia do zdarzeń zamkniętych w pamięci ${ }^{15}$.

W kontekście Zagłady niezwykłego znaczenia nabiera przekonanie, że istotą fotografii jest nawiedzanie naszej pamięci i przywracanie życia wspomnieniom ${ }^{16}$. W tym Barthesowskim stwierdzeniu pobrzmiewa sugestia dotycząca obecności świata równoległego, naznaczonego śmiercią, zamieszkałego przez zjawy, duchy, cienie. Fotografia konstytuuje pewien tryb przedstawiania rzeczywistości, którego istotę stanowi „samowycofywanie”. W ten sposób staje się wizualną alegorią umierania ${ }^{17}$. Co więcej, będąc swego rodzaju dowodem, że coś istniało, w sposób naturalny potwierdza, że istniał przedstawiony w utworze Drndić świat żydowskiego mieszczaństwa. Jednocześnie poświadcza prawdę Holokaustu poprzez to, czego na niej nie widać, a co jest odbiorcy znane $\mathrm{z}$ historii, jak również poprzez pośrednie wskazywanie na brak, pustkę, która pozostała.

Warto dodać, że niektóre postaci ze zdjęć patrzą w nieokreślony punkt w przestrzeni, inne zaś spoglądają wprost w obiektyw, a zatem prosto na nas, co sprawia, że mamy iluzję odwzajemnionego spojrzenia. Owo spojrzenie nas niejako „łapie”, wy-

13 D. Drndić, April u Berlinu, op. cit., s. 221, 222, 226.

${ }^{14}$ U. Baer, Umiejscowić pamięć: współczesna fotografia, Holokaust i tradycja pejzażu, w: Pamięć i afekty, red. Z. Budrewicz, R. Sendyka, R. Nycz, Warszawa 2014, s. 267.

15 M. Michałowska, Foto-teksty. Zwiąki fotografii z narracja, op. cit., s. 198.

16 Nawiedzenie teraźniejszości przez przeszłość jest centralnym motywem Światła obrazu Rolanda Barthesa. Wielokrotnie tę metaforę wykorzystuje Marianna Michałowska w swej książce, Obraz utajony. Szkice o fotografii i pamięci, Kraków 2007. Zob. też, A. Ubertowska, Rysa, dukt, odcisk. O spektrologiach Zagłady, „Teksty Drugie” 2016, nr 2, s. 102-121.

17 Zob. A. Ubertowska, Świadectwo-trauma-głos. Literackie reprezentacje Holokaustu, op. cit., s. 214. 
stawia na widok spokoju fotografowanych, ich pogody, niejednokrotnie uśmiechu, jaki został uwieczniony na zdjęciach. Mimo przemożnego efektu rzeczywistości [...], fotografie same w sobie sa [jednak - S.G.] wypowiedziami fragmentarycznymi i niepetnymi ${ }^{18}$. Pozbawione notki ustanawiającej kontekst mogłyby „oszukać” odbiorcę. Te obrazy, niemające $\mathrm{w}$ sobie nic $\mathrm{z}$ dramatyzmu, zostają jednak automatycznie skonfrontowane z naszą wiedzą o losie ludzi, których portrety oglądamy. Uruchomienie znaczenia za pośrednictwem krótkiej wzmianki o losie fotografowanego, sprawia, że [t]o, co widzimy teraz na zdjęciu nie jest tym, co kiedyś widzial fotograf. Patrzac na rzeczywistość widze nie tylko to, co spostrzegaja moje oczy, lecz także to, czego dowiedzieliśmy się $w$ czasie pomiędzy tamtym postrzė̇eniem $i$ współczesnym przeżyciem $^{19}$.

Nie będzie chyba nadużyciem jeśli uznamy, że Drndić nie pozwala odbiorcy na komfortowy odruch oburzenia i współczucia, podważa wygodną pozycję, prowokuje do jej przemyślenia i - w końcu - wymaga od czytelnika czegoś więcej, a mianowicie zastanowienia się nad moralną odpowiedzialnością nie tyle za zbrodnie, ile - jak się wydaje - za zapomnienie o ofiarach, za oswojenie się ze świadomością o istnieniu Holokaustu. Nieustanne konfrontowanie przeszłości z teraźniejszością, jakie ma miejsce w książkach Drndić, sytuuje czytelnika bowiem w relacji do Zagłady, stawia nas wobec niej. Odbiorca staje się w ten sposób spóźnionym świadkiem. Wpisana w zdjęcia Żydów wiedza o ich losie jest Barthesowskim punctum, w którym obecna jest równoważność przeszłości i przyszłości. Przypomnijmy, że badacz szuka w fotografii tego elementu, który odbiorcę przeszywa, będąc jakby znakiem uczynionym przez zaostrzony przedmiot, stanowi ranę ${ }^{20}$. To, co nas porusza (powinno poruszyć - zdaniem Drndić), gdy patrzymy na zdjęcia Żydów, to obecne w nich sprasowanie Czasu: to jest już martwe i to dopiero umrze ${ }^{21}$. Fotografia u Drndić ma nie tylko zadanie przeniesienia nas w przeszłość, równie ważną jej rolą jest przywrócenie przeszłości teraźniejszości. Można by wręcz powiedzieć, że u Drndić mamy opowieść o znikaniu i powrocie, co zresztą wydaje się być stałym motywem jej książek. Autorka wielokrotnie deklaruje, że jej zdaniem przeszłość wciąż się czegoś od nas domaga, że - za jej pośrednictwem - dopomina się o uwagę współczesnych. Efektem tej uwagi i wyczulenia na przeszłość może stać się podważanie, a nawet zrewidowanie tożsamości wspólnoty, co - jak się wydaje - jest jednym z zamierzeń pisarki.

Kompleksowe archiwum (przypomnijmy, że autorka mówi o jednej setnej zebranego materiału, który umieściła w książce), które pisarka tworzy, wytrącić ma nas

${ }^{18}$ A. Sekula, Spoteczne użycia fotografii, w: idem, Czytanie archiwum. Fotografia między praca a kapitatem, przeł. K. Pijarski Warszawa 2010, s. 119.

${ }^{19}$ M. Michałowska, Obraz utajony. Szkice o fotografii i pamięci, op. cit., s. 142.

${ }^{20}$ R. Barthes, Światto obrazu. Uwagi o fotografii, przeł. J. Trznadel, Warszawa 2008s. 51. I dalej badacz pisze: „Punctum” to także użadlenie, dziurka, plamka, małe przecięcie - ale również rzut kośćmi. Punctum jakiegoś zdjęcia to przypadek, który w tym zdjęciu celuje we mnie [me point] (ale też uderza mnie, miażḋy). Ibidem, s. 52.

${ }^{21}$ Ibidem, s. 171. 
z obojętności, zmuszając do namysłu nad naszą pozycją wobec niegdyś żyjących/ mieszkających w tym miejscach, w których dziś przebywamy, uznając je za swoje. Jednak w książce owej kilkustronicowej próbnej wersji nieistniejącego albumu, będącego $\mathrm{w}$ istocie efektem zbierackiej pasji, towarzyszą gorzkie refleksje. Autorka pyta wręcz: Ale kto by taki album wydał? Już teraz ludzie mi mówia, że ich zamęczam tymi imionami, tym wyliczaniem, tym katalogowaniem [...], coś się tak tego uczepiła, mówia $[\ldots]^{22}$.

\section{PRZEDMIOTY}

Fotografie znajdujące się w książce Drndić, wykorzystane zostają jako rodzaj dokumentu, a zarazem obraz afektywny. Są niejako rzutowane na naszą wiedzę o tym, że to my-współcześni Europejczycy zamieszkujemy domy portretowanych, że to my niejednokrotnie pijemy z kupionych na pchlich targach filiżanek, które przecież niegdyś do kogoś należały. Również te przedmioty, których właścicieli od dziesięcioleci już nie ma, których nazwiska pozostają nieznane, stają się swego rodzaju materialnym śladem ich bycia, na co zwraca uwagę Drndić:

[F]unkcja metonimicznego istnienia przedmiotu odsyła ku ludziom niegdyś go używającym lub posiadającym. Rzeczy snują narracje o człowieku i jego śmierci i tym samym wywołują szczególne zderzenie pomiędzy teraźniejszością a przeszłością, pomiędzy zbiorowiskiem ocalałych przedmiotów a całością życia ${ }^{23}$.

Drndić bardzo wyraźnie wiąże przedmioty z ich właścicielami. Jej zdaniem konfiskata mienia (w książce $E E G$ wymienia przykładowe rzeczy, które z żydowskich domów zwykle trafiały do Niemców), oznacza kradzież tego wszystkiego, co tworzy życie, a tak naprawdę kradzież żcia tym, którym zostało ono fizycznie odebrane ${ }^{24}$. Te przedmioty (np. filiżanki kupione na targach Europy) tworzą w przekonaniu Drndić kolekcję czyichś dni, zbiór skradzionych, za niewielka kwotę kupionych radości i rozpaczy, toastów i upamiętniajacych mów, które [...] niczym ciche dzwoneczki zawiadamiaja [...] o każdym przemoca przerwanym trwaniu ${ }^{25}$. Ujawnia się w tym miejscu podwójna natura spisów i archiwów, jaka dochodzi do głosu w kontekście Zagłady. Tabele (umieszczone w utworze $E E G$ ), zawierające skatalogowany majątek żydowski, który wcześniej został skrupulatnie sfotografowany, służą do metonimicznego przywołania ich właścicieli, są ponadto jednoznacznym dowodem winy. Te rzeczy

\footnotetext{
${ }^{22}$ Drndić, April u Berlinu, op. cit., s. 230. Jeśli nie zaznaczono inaczej, wszelkie wyróżnienia pochodzą od prozaiczki.

23 B. Shallcross, Rzeczy i Zagłada, Kraków 2010, s. 8.

24 D. Drndić, EEG, op. cit., s. 297.

25 Ibidem, s. 298.
} 
(skatalogowane, policzone i dokładnie opisane) poświadczają istnienie, ale jednocześnie poświadczają śmierć.

Dla porząaku dodać należy w tym miejscu, że już od czerwca $1941 \mathrm{r}$. w Chorwacji obowiązywało prawo, które umożliwiło systematyczny, dokonywany na ogromną skalę rabunek mienia żydowskiego ${ }^{26}$. Jak zauważa Drndić rabowano nie tylko drogocenne przedmioty, ale i - służące do codziennego użytku - bezwartościowe rzeczy: tyżki, talerze, sztućce, pościel, ubrania, buty, bieliznę, a nawet żarówki, gwoździe, narzędzia, zastony, obrusy, koce, poduszki, patelnie, garnki i czajniki, dziecięce zabawki, od lalek i pitek do samochodzików i elektrycznych kolejek [...] $]^{27}$. Te niejednokrotnie zdekompletowane przedmioty (przedmioty-śmieci, resztki) wciąż trafiają na pchle targi. Te stosy odpadów zalegające świat tworzą - w ujęciu Aleidy Assman - „negatywny magazyn”, antynomię archiwum, będącą wedle badaczki obrazem pamięci niejawnej. A granica pomiędzy archiwum, a śmietnikiem wydaje się być ruchoma ${ }^{28}$. Przedmioty codziennego użytku, które trafiają w ręce współczesnych, mogą (jeśli zachowają w naszej pamięci związek z osobą, do której należały), metaforycznie przedłużyć życie zamordowanym. Drndić zdaje się pragnąć (niespecjalnie ufając pamięci instytucjonalnej), abyśmy przeszłość zobaczyli w resztkach, które po niej pozostały. Archiwum utożsamiane bywa z opresją i władzą. Niewątpliwie instytucja ta jest ściśle powiązana z pamięcią obowiązującą, usankcjonowaną oficjalnie. Podążając za myślą Assman można by powiedzieć, że możliwa jest zamiana miejsc: tego, co aktualnie zostało zmagazynowane i uznane ze nadrzędne $\mathrm{z}$ tym wszystkim, co dziś zapełnia śmietniki, wysypiska. Michałowska w tym kontekście odwołuje się do opozycji archiwum aktywnego i uśpionego ${ }^{29}$. Uśpione archiwum oznacza archiwum potencjalne. I właśnie to, co potencjalne, tymczasowo pozostające na marginesie interesuje Drndić.

\section{PRZESTRZEŃ}

Warto zaznaczyć, że zabiegi umożliwiające wtargnięcie minionego w teraźniejszość pojawiają się w twórczości Drndić w różnych formach. Jak to już zostało zasygnalizowane, w ostatniej powieści $(E E G)$ autorka stosuje analogiczny chwyt, jak w utwo-

${ }^{26}$ Narcisa Lenger Krizman, przywołując oceny badaczy, zrabowany Żydom na terytorium kolaborującego z nazistami NDH majątek (chorw. Nezavisna Država Hrvatska, pol. Niezależne Państwo Chorwackie) wycenia na 25 miliardów (nie podaje waluty). Przypis w: N. Lenger Krizman, Logori za Židove u NDH, w: Zna li se 1941-1945. Antisemitizam-Holokaust-Antifašizam, red. O. Kraus, Zagreb 1996, s. 93.

${ }^{27}$ D. Drndić, EEG, op. cit., s. 297.

${ }^{28}$ A. Assman, Formy i przemiany pamięci kulturowej, przeł. P. Przybyła, w: Pamięć zbiorowa i kulturowa. Wspótczesna perspektywa niemiecka, red. M. Saryusz-Wolska, Kraków 2009, s. 115.

${ }^{29}$ Michałowska nawiązuje w tym miejscu do rozważań Alana Sekuly, Czytanie archiwum, s. 119, za: M. Michałowska, Foto-teksy. Związi fotografii z narracja, op. cit., s. 269-270. 
rze April u Berlinu. Reaktywując przeszłość zmienia jedynie medium (przechodzi od wizualnego do narracyjnego), zaś zasada, wedle której tego dokonuje, pozostaje ta sama. W utworze EEG mianowicie zderza ze sobą dwie opowieści. Opisuje miejsca znajdujące się w dzisiejszym centrum Zagrzebia: modne, głośne, wypełnione zabawą, a więc pełniące w stolicy Chorwacji funkcje ludyczne ${ }^{30}$. Tę przestrzeń zestawia $\mathrm{z}$ - prawdopodobnie częściowo wyimaginowanym - „obrazem w ruchu” tego samego miejsca sprzed lat siedemdziesięciu. Niepewność dotycząca statusu ontologicznego postaci, wydarzeń i specyfiki opisywanego wycinka rzeczywistości, pozwala mówić w tym kontekście o fantazji i zmyśleniu. Jednak skoro współcześnie trudno doszukać się znaków tej konkretnej (żydowskiej) przeszłości w tkance miasta, to można uznać, że jedynie osadzona w realności fikcja może umożliwić uobecnienie przeszłości. Drndić uzupełnia okaleczoną nieobecnością rzeczywistość ${ }^{31}$, poprzez zakotwiczenie zmarłych w naszym świecie. Współczesne centrum chorwackiej stolicy (zgodnie ze swym przeznaczeniem) jest wypełnione beztroską zabawą, a zatem wydaje się być neutralne afektywnie. Pisarka prezentuje swoiste scenki z życia żydowskich mieszkańców Zagrzebia, wskazując na niespójność pomiędzy współczesnością przywoływanej przestrzeni, a jej przeszłością. Pośrednio również w tych fragmentach odwołuje się do wypartej winy i odpowiedzialności.

Przywołajmy w tym miejscu dwa z tego rodzaju opisów:

Szewc Gabriel Kalderon, urodzony w Bitoli w 1901 r., mieszka przy Vlaškiej 94. Z Bitoli do Zagrzebia przeprowadza się w 1932 r. Mieszka z żoną i czwórka dzieci. Zgłaszając swój majątek władzom NDH, informuje, że w zakładzie ma 120 par butów czekających na naprawę, a jego narzędzia są warte 300 dinarów. Jego najstarszego syna - osiemnastoletniego Jakova - zabito w ustaszowskim obozie Jadovno, a on Gabriel Kalderon, wraz z pozostałymi przy życiu członkami rodziny zostaje złapany w 1943 r. i deportowany do Auschwitz. Widzimy go jak na parterze przy Vlaškiej 94, w swoim spowitym mrokiem zakładzie, siedzi na niskim stołku i obraca znoszony damski but. Obok niego siedzi chłopiec, który o coś stuka, a przez okno na piętrze widać pochyloną nad kuchenką kobietę, która jedną ręką miesza coś w garnku, a drugą przytrzymuje na boku śmiejącą się dziewczynkę. Spod tego ogromnego, ruchomego obrazu prześwieca szyld sklepu Pletix, w którym tu, przy Vlaškiej 94, można kupić kostiumy kąpielowe i bieliznę, a zaraz obok widać salon fryzjerski Trans-X, w którym z fryzjerskim hełmem na głowie siedzi kobieta z i czyta „Glorię”,

Idziemy na Vlaszką 63. Przy Vlaszkiej 63, Avram Levi, syn Davida Leviego, urodzony w $1911 \mathrm{r}$. w Sarajewie, stoi za ladą swego małego sklepiku z ubraniami i butami, patrzy na ulice i zastanawia się czy tego dnia zdoła coś sprzedać. Spoza kadru dociera zapach dopiero co wypieczonych włoskich placków z pizzerii Kariola Vlaszka, goście piją piwo, przebierają palcami po swoich mądrych tele-

30 Jak wynika z mapy, na której zostały zaznaczone najważniejsze instytucje zagrzebskiej społeczności żydowskiej, większość z nich znajdowała się w dzisiejszym centrum stolicy Chorwacji, a dokładnie w obrębie tzw. Dolnego Miasta. Zob. Židovski Zagreb. Kulturno-povijesni vodič, red. A. Laslo, Zagreb 2011.

31 Określenie „okaleczona nieobecnością rzeczywistość” pochodzi z tekstu Romy Sendyki, Miejsca, które straszą (afekty i nie-miejsca pamięci), w: Pamięć i afekty, op. cit., s. 295. 
fonach i obojętnie wkładają do ust ciepłe trójkąty. /Avrama Leviego w 1942 r. w Jasenovacu zabijają ustasze ${ }^{32}$.

Drndić każe nam zajrzeć w przeszłość, zabawić się przez chwilę w podglądacza, który ma szansę z bliska przyjrzeć się życiu tuż przed jego końcem. Te konkretne jednostki (szewc, jego żona gotująca obiad, maleńka córeczka) zostaną wkrótce unicestwione. Drndić chodzi o pokazanie nie tyle masy, ile człowieka oraz o zdanie sprawy ze zbliżającego się konkretnego cierpienia (skala mikro) ${ }^{33}$.

Dla porządku wskazać należy na kilka podstawowych faktów odnoszących się do kwestii zagłady chorwackich Żydów. Należy podkreślić, że jeszcze przed utworzeniem NDH, a dokładnie w 1940 r., na terytorium Banowiny ${ }^{34}$ wprowadzone zostały pierwsze ustawy ograniczające prawa Żydów ${ }^{35}$. W kwietniu 1941 r., po kapitulacji Jugosławii, powstaje NDH, w którym nasilają się akcje zmierzające do likwidacji społeczności żydowskiej. Początkowo aparatem represji kierują Niemcy (manifestacje antysemickie, rabunki mienia żydowskiego, przejmowanie sklepów, aresztowania przez Gestapo itp.), a następnie akcjami dowodzą sami ustasze. W kontekście prozy Drndić szczególnego znaczenia nabiera wyrażone przez Goldsteina przekonanie, że Zagrzeb stał się doskonałym poligonem, na którym sprawdzano możliwość realizacji antyżydowskich planów reżimu. W stolicy bowiem mieszkała praktycznie jedna trzecia przedstawicieli chorwackiej społeczności żydowskiej, a ponadto społeczność ta była najbogatsza $\mathrm{w}$ kraju ${ }^{36}$. Zatrzymania Żydów rozpoczynają się wraz z proklamowaniem NDH, jednak pierwsze masowe aresztowanie (równoznaczne z likwidacją) miało miejsce w maju. Wówczas 165 młodych ludzi zostało przetransportowanych najpierw do obozu przejściowego, a następnie do obozu Jadovno (w pobliżu Gospicia), w którym prawie wszyscy (oprócz 10 osób) zostali zamordowani ${ }^{37}$. Miejscem przeznaczonym do koncentracji ludności żydowskiej w chorwackiej stolicy stał się zagrzebski kompleks wystawienniczy (Zagrebački zbor). W jego skład wchodziły pawilony, które powstały w latach $30 \mathrm{XX}$ w., pomiędzy dwoma, w okresie międzywojennym niezwykle nowoczesnymi, fabrykami ${ }^{38}$. Miejsce to przez pewien

32 Jasenovac - oznacza kompleks złożony z pięciu obozów, który w latach 1941-1945 działał na terytorium NDH. D. Drndić, EEG, op. cit., s. 322-323.

${ }^{33}$ Wiosną 1942 r. ponad połowa zagrzebskich Żydów została przetransportowana do obozów w Jasenovacu oraz Loborgradzie i Đakovie (kobiety i dzieci). Dwie z ostatnich masowych deportacji miały miejsce w sierpniu 1942 r. i w maju 1943 r. Wówczas policja aresztowała większość pozostałych w Zagrzebiu Żydów i przekazała ich nazistom, którzy następnie deportowali ich do Auschwitz. Zob. I. Goldstein, Zagreb 1941-1945., Zagreb 2011, s. 143.

${ }^{34}$ Chorwacka Banowina oznacza autonomiczne terytorium zamieszkałe przez Chorwatów, istniejące od 1939 r. do 1941 r. w ramach Królestwa Jugosławii.

${ }^{35}$ Zob. I. Goldstein, Holokaust u Zagrebu, współautor S. Goldstein, Zagreb 2001, s. 73-74.

${ }^{36}$ Zob. ibidem, s. 123-124.

${ }^{37}$ Ibidem, s. 249-251.

${ }^{38}$ S. Leboš, Kultura promjene, https://www.academia.edu/11046690/Kultura_promjene, s. 8 [dostęp: 11.01.2018]. 
czas pełniło funkcję obozu tranzytowego, gdzie internowani Żydzi podlegali selekcji i stamtąd w większości przypadków kierowani byli do obozów koncentracyjnych w Danicy, Gospiciu, Jadovnie, na wyspę Pag, a potem również do Jasenovaca. Jak zauważa Goldstein miejsce to zostało precyzyjnie wybrane: ze względu na swe usytuowanie stanowiło przestrzeń, której łatwo było strzec, a ponadto w jego bezpośrednim sąsiedztwie znajdowały się tory, co ułatwiło deportację $e^{39}$.

W przypadku Drndić, bezpośrednim impulsem do tworzenia pojedynczych kadrów z przeszłości jest praca Shimona Attie'go z lat 1991-1992, amerykańskiego fotografa i artysty wizualnego, który na współczesnych fasadach budynków w berlińskiej dzielnicy niegdyś zamieszkałej przez Żydów, wyświetla zdjęcia z czasów poprzedzających wybuch drugiej wojny światowej. W ten sposób dopełnia rzeczywistość, nadbudowując na tym, co teraźniejsze to, co istniało w tej przestrzeni niegdyś, a tym samym przeszłość reaktywuje. W kontekście twórczości Drndić można powiedzieć, że udaje się jej nadać brakowi, pustce obecnej we współczesnym Zagrzebiu, formę widzialną. Zarówno Attie, jak i Drndić fundują pamięć na doświadczeniu przestrzennym. Konkretne miejsce zostaje niejako wpisane w podwójną ramę: istnieje jednocześnie w teraźniejszości i przeszłości, a nałożenie się obu planów tworzy nową jakość, w której minione zostaje przywrócone aktualnemu. Autorka wpisuje się w ten sposób w pewien rodzaj diagnozowania straty, w którym akcentowany zostaje fakt wytrawienia pamięci i przestrzeni. Nieobecność zaś (zarówno fizyczna, rozumiana jako brak społeczności, ale i nieobecność znaku ją symbolizującego, jak i mentalna, oznaczająca wyparcie) wynika z pewnych przesunięć w obrębie pamięci zbiorowej, które sprawiają, że współcześni mieszkańcy miasta żyją w swoistej nieświadomości.

\section{TRUDNE DZIEDZICTWO}

W tym kontekście niniejsze rozważania można uzupełnić o informacje ściśle związane z losem chorwackich Żydów, a dotyczące przywoływanej powyżej zagrzebskiej przestrzeni, a mianowicie terenów dawnych targów. Jak to już zostało zasygnalizowane w czerwcu, lipcu i sierpniu 1941 r. Zagrebački zbor stanowił centralny punkt tranzytowy w drodze chorwackich Żydów do obozów. Według Goldsteina przewinęło się przez niego około 2500 osób $^{40}$. Dzisiaj tereny te wchodzą w skład kompleksu Studenckiego Centrum Zagrzebia.

Sonja Leboš w tekście, będącym w istocie polemiczną recenzją książki zatytułowanej Prostorna studija Studentskog centra Sveučilišta u Zagrebu, wielokrotnie podkreśla fakt wybiórczej pamięci o tym miejscu, której analizowana publikacja jest dowodem. Wskazuje mianowicie, że w tomie trudno odnaleźć informacje o roli, jaką

39 S. Goldstein, Holokaust u Zagrebu, op. cit., s. 252.

40 Następnie jego funkcję przejął punkt tranzytowy usytuowany we wschodniej części Zagrzebia, a mianowicie w dzielnicy Zavrtnica. Zob. I. Goldstein, Holokaust u Zagrebu, op. cit., s. 261. 
pełniła ta przestrzeń w okresie istnienia NDH. Tego typu „niedopatrzenie” autorka tekstu określa mianem „wymazywania kulturowej pamięci miejsca”, której kulminację odnajduje w fakcie, że na miejscu istnienia obozu tranzytowego nie ma (i nigdy nie było) tablicy upamiętniającej, bądź też innego znaku wskazującego na jego funkcję w czasie wojny ${ }^{41}$. Byłby to bowiem potencjalnie niebezpieczny znak ,trudnego dziedzictwa”, by posłużyć się terminem Sharon Macdonald. Jest ono kłopotliwe, bo zagraża niszczacym wtargnięciem przeszłości w teraźniejszość: jest potencjalnym zapalnikiem, grożacym otwarciem spotecznych podziatów ${ }^{42}$. Brak znaków świadczących o historii miejsca jest uznany przez chorwacką badaczkę za pewien rażący brak, niedostatek, ale i niesprawiedliwość ${ }^{33}$. Ta nieobecność upamiętniającego artefaktu w sposób dialektyczny połączona jest z wstydliwym znikaniem żydowskich mieszkańców Zagrzebia w czasie wojny ${ }^{44}$. Drndić tego typu wyparciom i „niedopatrzeniom" wyraźnie się przeciwstawia, między innymi poprzez literacką rekonstrukcję przestrzeni Zagrzebia z lat 40 -tych ${ }^{45}$. Zderzając kadry z przeszłości z aktualnym obrazem miejsca, wskazuje także na widmowy charakter centrum chorwackiej stolicy, jego subwersyjność. Za sprawą „wymazywania kulturowej pamięci miejsca” nieobecność tych, których już nie ma, staje się podwójna: są nieobecni faktycznie i symbolicznie, bo brakuje śladów wskazujących na ich niegdysiejszą obecność.

Niewątpliwie każda pamięć kolektywna jest wybiórcza, pomija niewygodne fragmenty przeszłości, zbudowana jest na dialektyce pamiętania i zapomnienia. Fakt, że nadrzędna narracja o przeszłości, która obowiązywała po drugiej wojnie świato-

${ }^{41}$ Zob. S. Leboš, Kultura promjene, op. cit., s, 15-16. Tom, będący przedmiotem krytyki autorki artykułu: Prostorna studija Studentskog centra Sveučilišta u Zagrebu, red. H. Auf-Franić, Zagreb 2007. W 2014 r. miało miejsce otwarcie odrestaurowanego tzw. francuskiego pawilonu, wchodzącego w skład międzywojennego kompleksu wystawienniczego. Chorwacki publicysta Saša Šimpraga, w maju 2014 r., na swoim blogu poświęconym przestrzeni publicznej chorwackiej stolicy, podkreślił konieczność oznaczenia tego miejsca ze względu na rolę, jaką pełniła ona w czasie „ostatecznego rozwiązania”. A to dowodzi, że nie zrobiono tego $\mathrm{w}$ trakcie prac renowacyjnych. http://zagrebjavniprostor.tumblr.com/post /84447866718/obnova-francuskog-paviljona-u-sklopu-zagreba\%C4\%8Dkog [dostęp: 12.01.2018].

${ }^{42}$ S. Macdonald, Difficult Heritage: Negotiating the Nazi Past in Nuremberg and Beyond, London 2008, za: R. Sendyka, Co widać z góry. Inne miasto i jego trudne dziedzictwo, http://pismowidok.org/index.php/one/article/view/144/197 [dostęp: 17.11.2017].

${ }^{43} \mathrm{Na}$ marginesie dodajmy, że w stolicy Chorwacji podejmowane są działania mające na celu przywracanie pamięci. Ich efektem był chociażby (połączony z prelekcjami) spacer po nierzadko zapomnianych, choć ważnych miejscach stolicy związanych z cierpieniem i traumą z lat drugiej wojny światowej. Zagrzebska Wędrówka śladami umartych miała miejsce w 65 rocznicę wyzwolenia miasta. Więcej na ten temat: S. Zorić, Kultura zaborava - upoznavanje nepoznatog Zagreba, http://www.lupiga.com/vijesti/kultura-zaborava-upoznavanje-nepoznatog-zagreba [dostęp: 05.02.2018].

${ }^{44}$ Ten wątek jest jednym z centralnych motywów powieści Miljenka Jergovicia Ruta Tanenbaum, przeł. M. Petryńska, Wołowiec 2008. Oryginalną interpretację powieści przeprowadziła Kinga Sewior w tekście Stawiając opór nieistnieniu. Ruta Tannenbaum Miljenka Jergovicia jako narracja postraumatyczna, „Porównania” 2013, nr 12, s. 117-136.

${ }^{45}$ O polskich twórcach, którzy powracają w swych tekstach do „miejsc wydrążonych z pamięci” pisze Elżbieta Rybicka w rozdziale Topografie historii: miejsce, pamięć, literatura, w: idem, Geopoetyka. Przestrzeń i miejsce we współczesnych teoriach i praktykach literackich, Kraków 2014, s. 297-324. 
wej w Jugosławii oparta była na niwelowaniu złożoności historii wojny na terenie Jugosławii i na pamięci o wspólnej walce z faszyzmem jest powszechnie znany. Jej dominujący status wypierał ,małe” narracje o żydowskim cierpieniu, a ono samo było niejako zawłaszczane przez opowieść o partyzantach ${ }^{46}$. Po rozpadzie Jugosławii zaś opowieść o kolaboracyjnym państwie chorwackim z czasów wojny stała się niewygodna, podważała bowiem pozytywny autostereotyp społeczności.

Przypomnijmy, że Macdonald w kontekście przestrzeni, z której zniknęły ślady konfliktowej przeszłości, mówi o dziedzictwie, które jest na widoku, a jednak nie jest całkiem widoczne. Jest świadectwem przeszłości, której powrót niszczy dzisiejsza samoocenę, identyfikację, narusza podwaliny tożsamości tej grupy, która zamieszkuje dany obszar ${ }^{47}$. Pewne działania artystyczne (zarówno Attie'go, jak i chorwackiej prozaiczki) są próbą opracowania w materii sztuki przekonania, wyrażonego przez Drndić, że [w]spomnienia/pamięć i przestrzeń pozostaja w permanentnym klinczu, gdy się rozpada przestrzeń, to $w$ swoje podziemia wciaga wspomnienia, a bez pamięci, współczesność staje się chora, okaleczona, jest jakby kikutem rzeczywistości $[\ldots]^{48}$. Ponadto wydobycie ze ,śmietnika czasu" tego, co marginalne i celowo odsunięte w cień, daje możliwość nie tylko przypomnienia, ale również przyjęcia odpowiedzialności za przeszłość ${ }^{49}$.

\section{ZAKOŃCZENIE}

Analizowane tutaj fragmenty z ostatniej książki Dnrdić utrwalają pewne obrazy. Autorce udało się uchwycić obraz Zagrzebia w momencie ich odchodzenia. Ich specyfika nasuwa skojarzenia $\mathrm{z}$ fotografią, która zatrzymuje pewien wycinek rzeczywistości. Drndić sugestywnie łączy słowo z obrazem, wypowiada to, co zapomniane, korzystając z wizualno-tekstowej narracji i w ten sposób tworzy Księgi Pamięci. Do tej właśnie tradycji wydaje się nieustannie nawiązywać chorwacka autorka, która zapamiętale, w kolejnych swoich książkach przywraca tożsamość ludziom deportowanym czy zamordowanym w trakcie „ostatecznego rozwiązania”. Dokonuje tego poprzez wyposażanie swych utworów w treść niejako naddaną, uobecniającą się także za sprawą różnego rodzaju list i spisów. W sposób najbardziej wyraźny i odrębny dochodzi to do głosu w powieści Belladonna, której wewnętrzne okładki zostały wyposażone w rodzaj kopert. W nich zaś czytelnik odnajduje: nazwiska żydowskich dzieci z Hagi (2061), które zginęty w czasie wojny. Listę w 1985 r. przygotowała Kitty Coster. W kolejnych latach spis byt uzupetniany przez pracowników izraelskiej am-

${ }^{46} \mathrm{Na}$ temat udziału Żydów w partyzantce zob. J. Romano, Jevreji Jugoslavije 1941-1945. Žrtve genocida i učesnici narodno oslobodilačkog rata, Beograd 1980.

${ }^{47}$ R. Sendyka, Co widać z góry. Inne miasto i jego trudne dziedzictwo, http://pismowidok.org/index. php/one/article/view/144/197 [dostęp: 17.11.2017].

48 D. Drndić, EEG, op. cit., s. 321.

49 M. Michałowska, Foto-teksty. Zwiąki topografii z narracja, op. cit., s. 270. 
basady i Museonu” oraz ,, listę nazwisk żydowskich ofiar, które przebywaty w obozie w Šabcu (Serbia). Spis (zawierajacy 1055 nazwisk) powstat w 1945 r. w Belgradzie. Przechowywany jest w tamtejszym Żydowskim Muzeum Historycznym ${ }^{50}$. Na kopertach widnieje umieszczony w trzech językach napis (po łacinie, po hebrajsku i chorwac$\mathrm{ku}$ ): Requiescat in pace. Umieszczenie list nazwisk w książce ma podobne znaczenia jak rytuał odczytywania kolejnych nazwisk w miejscach odbywania się praktyk komemoracyjnych, a jego sens sprowadza się do symbolicznego znaku zachowania pamięci.

Warto także podkreślić, że kadry z życia miasta, obrazy z przeszłości przywołane w ostatniej powieści Drndić wpisują się w niezwykle często współcześnie eksploatowane przekonanie o szczególnym powiązaniu pamięci/historii z przestrzenią. Magdalena Saryusz-Wolska śledzi drogę, jaką przeszły badania przestrzenne i wskazuje na fakt, że zarówno w ramach rozważań spod znaku spacial turn, jak i niejako poprzedzających je urban studies znamienny moment wyznacza przejście od rozważań na temat przyszłości do koncentracji na przeszłości ${ }^{51}$. Autorka wskazuje, że pamięć miejsca zwykle reprodukuje pamięć władzy i jest zdominowana przez mechanizmy kapitalistyczne. Od tych - również - dobrze zakorzenionych rozpoznań przechodzi do stwierdzenia, że w przestrzeni publicznej rzadko znajdujemy świadectwa pamięci o grupach dyskryminowanych, bądź o grupach mniejszościowych ${ }^{52}$. Te konstatacje mogą stać się kontrapunktem wobec wyrażonej słowami narratora powieści $E E G$ krytyki dotyczącej publicznej przestrzeni w ojczyźnie autorki. Narrator mianowicie, spacerując po Paryżu, na każdym kroku zauważa tablice upamiętniające ofiary z czasów drugiej wojny światowej. Jego wściekłość wywołuje porównanie do Chorwacji, w której, jak twierdzi: nie natykam się na tyle tablic [...], nawet jeśli na jakieś natrafie, to sa to małe, prawie niewidoczne, wysoko powieszone tablice, na których słowa blakna, to sa sprofanowane tablice, uszkodzone młotem jakiegoś wściekłego przechodnia o zaćmionym umyśle [...]. [A]lbo na miejscu tych niegdyś przytwierdzonych plyt, na ścianach pozostały tylko ich ślady, kontury dawnych tablic, zeschly tynk, który się tuszczy i dziury po śrubach, którymi niegdyś je przymocowano [...]"53.

Drndić wskazuje na ukrytą w przestrzeni miasta kontr-narrację (choć prawdopodobnie przedrostek kontr - konotujący sprzeciw, jest w tym kontekście zbyt kategoryczny) będącą uzupełnieniem opowieści o miejscu, dodatkiem do dominującej i powszechnie przyjętej pamięci o centrum stolicy. W obrazach opracowanych przez chorwacką autorkę splata się przestrzeń z wizualnością. Utrwalone w nich zostają chwile z życia, powtórzmy: z życia, które w sposób nagły wkrótce zostanie przerwane. A jednocześnie obrazy te dowodzą istnienia swoistych warstw pamięci, któ-

50 Tak są zatytułowane obie listy. D. Drndić, Belladonna, Zaprešić 2012.

51 M. Saryusz-Wolska, Pamięć i miasto, w: eadem, Spotkania czasu z miejscem. Studia o pamięci i miastach, Warszawa 2011, s. 130-132.

52 Ibidem, s. 138.

53 D. Drndić, EEG, op. cit., s. 295. 
re w metaforyczny sposób zapisywane są w przestrzeni miejskiej ${ }^{54}$. Pojęcie warstw - poprzez aktualizację konotacji geologicznych ${ }^{55}$ - w kontekście badań pamięciologicznych akcentuje wertykalny aspekt przestrzeni, poprzez skojarzenie z nakładającymi się poziomami, utajonymi, ukrytymi pod powierzchnią warstwami, a jednak konstytuującym topografię konkretnego miejsca.

Projekt Chorwatki ma wiele wspólnego zarówno z podejmowanymi przez artystów niekonwencjonalnymi próbami upamiętnienia każdego życia (prace Christiana Boltanskiego, Shimona Attie'go,), jak i praktykami instytucji archiwizujących. Wynika on z przekonania o moralnym obowiązku współczesnych wobec umarłych. Jednak - jak się wydaje - oryginalność rozwiązań Drndić polega przede wszystkim na szczególnym podkreślaniu przekonania, że przeszłość nie jest dla nas zamknięta, że istnieje niezbywalna więź pomiędzy tym, co było niegdyś, a tym, co jest teraz. Aby to dostrzec należy jednak wyciągnąć ową łączącą je nić na światło dzienne. Jednocześnie pisarka odchodzi od prostego (,klasycznego”?) reprezentowania Holokaustu. Bliższe jest jej przekonanie, że należy rozpoznawać jego echa, wskazywać na jego powidoki we współczesnym świecie, ale też tropić sygnały wskazujące na niedostateczne wyeksponowanie pamięci Zagłady. Uprawiać zatem należy Boudrillardowską „,nekroperspektywę", która narzuca współczesnym rodzaj zobowiązania intelektualnego, polegający na myśleniu z perspektywy świata, którego już nie ma ${ }^{56}$. Samo zagadnienie Holokaustu zaś - temat obsesyjnie powracający w twórczości Drndić - wydaje się być szczególnie trudny do przepracowania w Chorwacji, kraju, który w czasie drugiej wojny światowej kolaborował z Hitlerem, kraju, w którym podczas tworzenia zrębów nowej tożsamości w latach 90-tych pewne środowiska niejednokrotnie relatywizowały okres wojenny.

\section{BIBLIOGRAFIA}

Adamczyk-Garbowska M., Uzupetnianie pamięci-izkor bicher jako świadectwo i inspiracja, w: Zagłada Żydów. Pamięć narodowa a pisanie historii w Polsce $i$ we Francji, red. B. Engelking, J. Leociak, D. Libionka, A. Ziębińska-Witek, Lublin 2006, s. 161-170.

Assman A., Przestrzenie pamięci. Formy i przemiany pamięci kulturowej, przeł. P. Przybyła, w: Pamięć zbiorowa i kulturowa. Współczesna perspektywa niemiecka, red. M. Saryusz-Wolska, Kraków 2009, s.101-142.

54 Saryusz-Wolska podkreśla, że w kontekście przekonania o warstwowym charakterze przestrzeni miejskiej zwykle przywołuje się takie pojęcia, jak palimpsest i wykopaliska (archeologia). M. SaryuszWolska, Pamięć i miasto, op. cit., s. 181-185.

55 Zob. R. Sendyka, Pryzma - zrozumieć nie-miejsce pamięci (non-lieux de memoire), ,Teksty Drugie" 2013, nr 1-2, s. 323-344.

56 Przytaczam za A. Ubertowska, Świadectwo-trauma-głos. Literackie reprezentacje Holokaustu, op. cit., s. 31. J. Boudrillard, Przejrzystość zła. Esej o zjawiskach skrajnych, przeł. S. Królak, Warszawa 2009, s. 105 . 
Baer U., Umiejscowić pamięć: współczesna fotografia, Holokaust i tradycja pejzażu, w: Pamięć i afekty, red. Z. Budrewicz, R. Sendyka, R. Nycz, Warszawa 2014, s. 245-283.

Barthes R., Światto obrazu. Uwagi o fotografii, przeł. J. Trznadel, Warszawa 2008.

Drndić D., April u Berlinu, Zaprešić 2009.

Drndić D., Belladonna, Zaprešić 2012.

Drndić D., EEG, Zaprešić 2016.

Drndić D., Sonnenschein. Powieść dokumentalna, przeł. D. J. Ćirlić, Wołowiec 2010.

Giergiel S., Ocalić pamięcią. Praktyki pamięci i zapominania we współczesnej prozie postjugosłowiańskiej, Opole 2012.

Goldstein I., Holokaust u Zagrebu, współautor S. Goldstein, Zagreb 2001.

Goldstein I., Zagreb 1941-1945., Zagreb 2011.

Jergović M., Ruta Tanenbaum, przeł. M. Petryńska, Wołowiec 2008.

Każda ofiara ma imię-Every victim has a name, Lublin 2014.

Kiš D., Encyklopedia umartych, przeł., D. Ćirlić-Straszyńska i Ch. Arvanitidis, Warszawa 1991, s. 5180.

Kopaliński W., Słownik wyrazów obcych i zwrotów obcojęzycznych z almanachem, Warszawa 2000.

Leboš S., Kultura promjene, https:/www.academia.edu/11046690/Kultura_promjene [dostęp: 11.01.2018].

Lukić J., Bol pamćenia i bol zaborava: (anti)povijesni romani Daše Drndić, „Treća” 2010, nr 2, s. 2334.

Michałowska M., Foto-teksty. Związi fotografii z narracją, Poznań 2012.

Michałowska M., Obraz utajony. Szkice o fotografii i pamięci, Kraków 2007.

Modi memorandi. Leksykon kultury pamięci, red. M. Saryusz-Wolska, R. Traba, współpraca J. Kalicka, Warszawa 2014.

Rewers E., Post-polis. Wstęp do filozofii ponowoczesnego miasta, Kraków 2005.

Romano J., Jevreji Jugoslavije 1941-1945. Žrtve genocida i učesnici narodno oslobodilačkog rata, Beograd 1980.

Rybicka E., Geopoetyka. Przestrzeń i miejsce we współczesnych teoriach i praktykach literackich, Kraków 2014.

Saryusz-Wolska M., Pamięć i miasto, w: eadem, Spotkania czasu z miejscem. Studia o pamięci i miastach, Warszawa 2011.

Sekula A., Czytanie archiwum. Fotografia między praca a kapitałem, przeł. K. Pijarski Warszawa 2010.

Sendyka R., Co widać z góry. Inne miasto i jego trudne dziedzictwo, http://pismowidok.org/index.php/ one/article/view/144/197 [dostęp: 17.11.2017].

Sendyka R., Miejsca, które strasza (afekty i nie-miejsca pamięci), w: Pamięć i afekty, op. cit., s. 285307.

Sendyka R., Pryzma - zrozumieć nie-miejsce pamięci (non-lieux de memoire), „Teksty Drugie” 2013, nr 1-2, s. 323-344.

Sewior K., Stawiając opór nieistnieniu. Ruta Tannenbaum Miljenka Jergovicia jako narracja postraumatyczna, „Porównania” 2013, nr 12, s. 117-136.

Shallcross B., Rzeczy i Zagłada, Kraków 2010.

Ubertowska A., Rysa, dukt, odcisk. O spektrologiach Zagłady, ,Teksty Drugie” 2016, nr 2, s. 102-121.

Ubertowska A., Świadectwo-trauma-głos. Literackie reprezentacje Holokaustu, Kraków 2007.

Zlatar A., Tekst, tijelo, trauma, Zagreb 2004.

Zna li se 1941-1945. Antisemitizam-Holokaust-Antifašizam, red. O. Kraus, Zagreb 1996.

Zorić S., Kultura zaborava - upoznavanje nepoznatog Zagreba, http://www.lupiga.com/vijesti/kulturazaborava-upoznavanje-nepoznatog-zagreba [dostęp: 05.02.2018].

Židovski Zagreb. Kulturno-povijesni vodič, red. A. Laslo, Zagreb 2011.

http://zagrebjavniprostor.tumblr.com/post/84447866718/obnova-francuskog-paviljona-u-sklopu-zagreba $\%$ C4\%8Dkog [dostęp: 12.01.2018]. 